Article

\title{
Are Credit-Based Internet Consumer Finance Platforms Sustainable? A Study on Continuous Use Intention of Chinese Users
}

\author{
Ming Chen ${ }^{1}$, Fan Yang ${ }^{2, *(D)}$ and Yongrok Choi ${ }^{2, *(D)}$ \\ 1 Department of Electronic Commerce, Guangdong University of Science and Technology, \\ Dongguan 523083, China; chenming199406@163.com \\ 2 Program in Industry Security Governance, Inha University, Incheon 22212, Korea \\ * Correspondence: yangf1995@gmail.com (F.Y.); yrchoi@inha.ac.kr (Y.C.)
}

check for updates

Citation: Chen, M.; Yang, F.; Choi, Y. Are Credit-Based Internet Consumer Finance Platforms Sustainable? A Study on Continuous Use Intention of Chinese Users. Sustainability 2021, 13, 13629. https://doi.org/10.3390/ su132413629

Academic Editor: Leonardo Becchetti

Received: 8 November 2021

Accepted: 7 December 2021

Published: 9 December 2021

Publisher's Note: MDPI stays neutral with regard to jurisdictional claims in published maps and institutional affiliations.

Copyright: (c) 2021 by the authors. Licensee MDPI, Basel, Switzerland. This article is an open access article distributed under the terms and conditions of the Creative Commons Attribution (CC BY) license (https:// creativecommons.org/licenses/by/ $4.0 /)$.

\begin{abstract}
Internet consumer finance platforms (ICFPs), as a new Internet financial model, have emerged and been widely adopted by Chinese as well as global online shoppers following the rapid growth of e-commerce. This emerging financial tool is, however, luring younger generations deep into debt. It jeopardizes the Sustainable Development Goal (SDG) 1-No poverty, bringing the sustainability of this consumer financial model into question. To aid the sustainable development of ICFP industry, this paper distinguishes two antecedents of continuous use intention for ICFP users: (1) satisfaction, as a sustainable determinant; and (2) impulsive buying, as a non-sustainable determinant. We found satisfaction $(b=0.452)$ has a larger positive effect on continuous use intention compared to impulsive buying $(b=0.229)$. Therefore, ICFPs should weigh heavier on technology innovation instead of seducing consumers' impulsive buying behavior. We also found that credit limit misconception poses the largest impact $(\mathrm{b}=0.483)$ on impulsive buying. In the near term, governments and ICFPs may initiate public programs to improve ICFP users' financial literacy in order to restrain their unsustainable impulsive buying behavior and cultivate their sustainable satisfaction on ICFP technology and service. Market regulators may build up institutional frameworks to tighten the abuse of financial platforms on credit issuing power and better foster sustainable entrepreneurship in this new financial platform business.
\end{abstract}

Keywords: internet consumer finance; ECT-IS theory; impulsive buying; continuous use intention

\section{Introduction}

The advent of e-commerce platforms and new Internet businesses-such as on-spot shopping, ride-hailing, and the like-has driven the growth of Internet consumer finance platforms (ICFPs) [1]. ICFPs are capable of not only dealing with diverse emerging e-businesses through online payment, but also in connecting traditional offline commercial activities through mobile payment. From 2014 to 2016, the annual growth rate of the Internet consumer finance market transaction scale exceeded $200 \%$ in China (Table 1). However, the market for ICFPs has been rapidly saturating in recent years. Annual transaction growth rate has dropped from $546.02 \%$ in its peak to $17.35 \%$ in 2019 . This shift indicates that China's Internet consumer finance industry is gradually entering a new stage of development, and there is an urgent need for ICFPs to shift toward retaining existing users for sustainable development.

A prominent way of ICFPs to retain users is abusing its credit issuing power. They provide easy-to-access credits that trap young generations into deep debt. In 2019, per capita debt owed by Chinese post-1990s young people had mounted to more than RMB 120,000 , a large amount of which can be ascribed to overspending in online shopping [2]. In this way, ICFP users have become ever reliant upon credit from ICFPs as they get deeper in debt. Meanwhile, their risk of debt default is also rapidly climbing. Ant Financial 
Services Group, the biggest ICFP in China, disclosed that their consumer credit balance overdue rate (D30+, D90+), has shown major upticks in recent years (Figure 1). Under this circumstance, ICFPs as well as industrial regulators should revisit the development strategy of this industry, otherwise the sustainability of ICFPs is at stake.

Table 1. China's Internet Consumer Finance Development Status (2011-2020).

\begin{tabular}{|c|c|c|c|c|}
\hline Year & $\begin{array}{c}\text { Consumer Finance Market Size/ } \\
100 \text { million RMB }\end{array}$ & $\begin{array}{c}\text { Internet Consumer Finance } \\
\text { Transaction Market Size/ } \\
100 \text { million RMB }\end{array}$ & $\begin{array}{c}\text { Internet Consumer Finance } \\
\text { Market Transaction Size } \\
\text { Growth Rate/\% }\end{array}$ & $\begin{array}{c}\text { Internet Consumer Finance } \\
\text { Penetration Rate } / \%\end{array}$ \\
\hline 2011 & $16,584.85$ & 6.8 & & 0.04 \\
\hline 2012 & $19,803.4$ & 18.6 & 173.53 & 0.09 \\
\hline 2013 & $27,130.01$ & 60 & 222.58 & 0.22 \\
\hline 2014 & $32,599.45$ & 183.2 & 205.33 & 0.56 \\
\hline 2015 & $40,170.31$ & 1183.5 & 546.02 & 2.95 \\
\hline 2016 & $49,618.96$ & 4367.1 & 269.00 & 8.8 \\
\hline 2017 & $84,673.3$ & 9983.4 & 128.60 & 11.79 \\
\hline 2018 & $106,657.68$ & $19,428.9$ & 94.61 & 18.22 \\
\hline 2019 & $122,473.17$ & 22,800 & 17.35 & 18.62 \\
\hline
\end{tabular}

Source: Authors' own compilation.

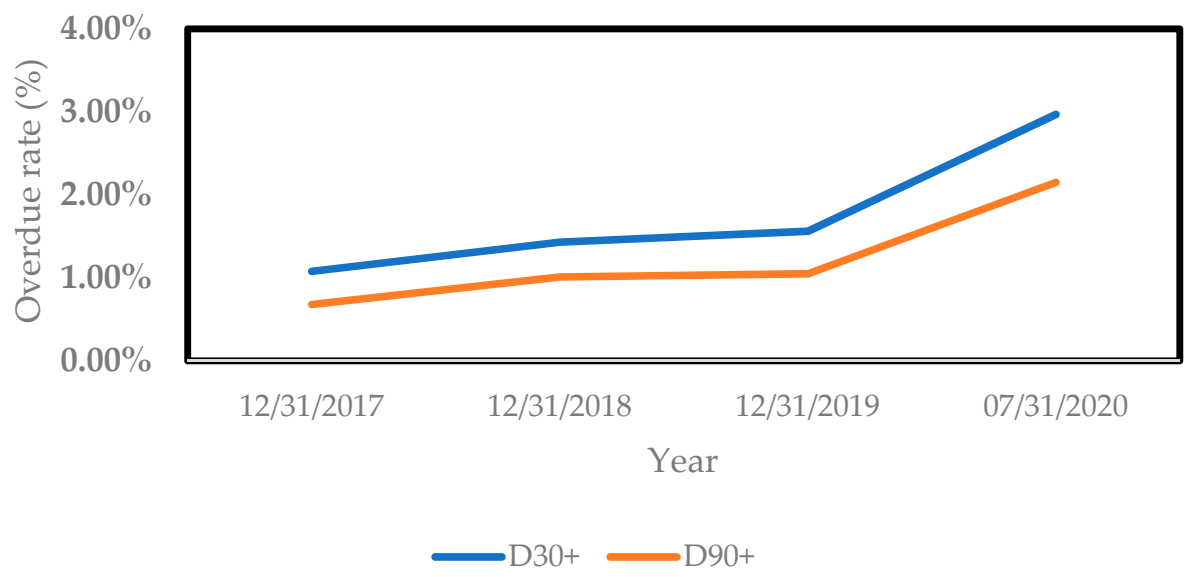

Figure 1. Ant Financial Services Group Consumer credit balance overdue rate. Source: Authors' own compilation. Note: 'credit balance overdue rate' is the principal balance of loans that are more than 30 days past due or 90 days past due as of a certain date (deduct loans that have been checked for reduction)/the total principal balance of loans facilitated by the company's platform (deduct loans that have been checked for reduction).

In this respect, we are going to re-evaluate the continuous use intention of ICFP users, the core of user retention, through a more comprehensive framework. In our study, we distinguish two contrasting antecedents of continuous use intention for ICFP users based the self-control theory, and the expectation-confirmation of information system theory (ECT-IS). The theoretical framework identifies two identities of ICFP users: consumers and information system users. As consumers, ICFP users may abuse consumer credits given by ICFPs and trap themselves into deep debt, making them financially unsustainable to continuously use the financial tool. As information system users, they may find the ICFPs useful to fulfill their rational purchases and improve their quality of life. We found that although impulsive buying driven primarily by credit misconception significantly affects continuous use intention, technological satisfaction plays a bigger role in determining continuous use intention of ICFP users. This finding helps us generate some practical implications for the sustainable development of ICFPs.

The remainder of this paper is organized as follows. In Section 2, we will review previous literature on ECT-IS and impulsive buying; in Section 3, we develop key concepts, propose hypotheses, and present our research model; in Section 4, the questionnaire data of the model and its results are analyzed; Section 5 concludes with practical implications 
and suggestions for the development of Chinese ICFP industry. Section 6 presents the concluding remarks.

\section{Literature Review}

\subsection{Continuous Use Intention in Expectation-Confirmation Theory of Information} System Continuance

The study of information system user intention and behavior originated from the technology acceptance theory (TAM) proposed by Davis [3]. The theory predicts and explains antecedents of initial acceptance of information system users, but neglects their post-acceptance intention and behavior. Post-acceptance behavior has been more widely studied for consumers. Special attention has been given to repeated purchase behavior. Oliver [4] proposed the expectation confirmation theory (ECT) to explain the repeated purchase behavior of consumers. Pee et al. [5] found that consumers' willingness to repeat the purchase of products will be enhanced when people's previous expectations for goods were met. Bhattacherjee [6] built a variant of the ECT theory-the expectationconfirmation theory of information system continuance (ECT-IS) - to explain the repeated use of information system. He found that users' expectation confirmation has a significant impact on satisfaction, which will further affect users' continuous use intention for the payment system of online banking. This theory is widely used to analyze the post-adoption behavior or behavioral intention of information technology users. Oghuma et al. [7] used the ECT-IS model to study the continuous use intention of Korean instant messaging service users, and found that the perceived service quality and perceived availability have a significant impact on user satisfaction and continuous use intentions. Rahi et al. also verified that perceived usefulness has a positive impact on satisfaction and continuous use intention for Internet banking users [8]. Shiau et al. [9] used the ECT-IS theory to analyze the continued use of financial technology. Zhou et al. [10] studied the e-finance continuance intention of China users with Alibaba's Yu'E Bao and found that website quality, familiarity, and situational normality can influence perceived ease of use and perceived usefulness. The two factors, together with reputation, are positively associated with confirmation which further leads to satisfaction, and ultimately continuance intention, of users.

\subsection{The Theory of Self-Control and Impulsive Buying}

ICFP users are not only information system users, but also online and offline consumers. Previous literature on the dual role of ICFP users is lacking. They mostly neglect the role of ICFP users as consumers. To study consumer behavior, existing papers mostly adopted the self-control theory. Self-control is an important component of individual self-psychological structure. It has been widely accepted to analyze irrational consumer behavior. KhanDhar and Wertenbroch [11] explained consumer self-control from the perspective of time preference, suggesting that consumer self-control is a conflict between consumers' long-term and short-term interests. The realization of long-term interests means that consumers have achieved self-control, and the realization of short-term interests means that consumers' self-control has failed. A typical irrational buying behavior is impulsive buying [12,13]. This kind of unplanned and temporary buying behavior can be seen as a manifestation of self-control failure. A typical failure of self-control or decreased self-control is impulsive buying behavior [14,15]. Failure of self-control often leads to over-indebtness. For example, Norvilitis and Mendes-da-Silva [16] confirmed that those students with a higher level of self-control would have lower levels of indebtedness. In contrast, Ottaviani, and Vandone [17] found that impulsiveness is associated with over indebtedness. Therefore, impulsive buying is conceived as an origin of individual financial instability.

Previous papers find many factors contribute to impulsive buying behavior, from situational factors to social influences. Impulsive buying is prone to occur in a shopping environment [18], and consumers' own characteristics may also trigger impulsive buying behavior $[19,20]$. Di et al. [21] found that prearranged lines of credit provided by credit 
card loans encourage impulsive buying behavior, and this leads to higher debt among credit card holders. Abrantes-Braga [22] studied the holders of credit card consumption and found that those who regard the credit card limit as an additional income-credit limit misconception-are more likely to produce impulsive buying behavior. Verplanken and Herabadi [23] constructed a scale to measure impulsive shopping from both cognitive and affective perspectives. Luo et al. [24] found that social exclusion has significantly positive effect on impulsive buying for Chinese college students. He et al. [25] found that reputation can be used to explain the high prevalence of compulsive buying among online buyers in China.

However, the understanding on the relationship between impulsive buying and continuous use intention has been lacking in the current literature, especially in the context of ICFPs. Yet, it is intuitively appealing to hypothesize that more impulsive buying behaviors may render greater dependence on loaning behavior-i.e., reliance on ICFPstherefore, increasing the continuous use intention of ICFP users. Thus, in this paper, we integrated ECT-IS theory with impulsive buying to analyze continuous use intention of ICFPs users.

\section{Research Model and Hypotheses}

\subsection{Expectation-Confirmation Theory of Information System Continuance (ECT-IS)}

The ECT-IS theory constructs three variables to directly and indirectly explain users' continuous use intention: the level of satisfaction with information system; the extent of the user's confirmation of expectations; and the users' perceived usefulness of information systems.

\subsubsection{Satisfaction, Confirmation, and Perceived Usefulness}

The expectation-confirmation model posits that the past confirmation of a user's expectation will have a positive effect on the perceived usefulness of an information system and on user satisfaction [6]. Here, confirmation is defined as the extent to which an individual's actual experience is consistent with his or her initial expectation [26]. That is, users will have an initial expectation of the functions and effects of applications before use. If their expectation matches their actual experience, their satisfaction increases. Then, they are more likely to continue to use the new applications. Oliver [4] defined satisfaction as the expected level and the function of the degree of confirmation. He suggested satisfaction is affected by both the perceived usefulness and the expected degree of confirmation. The research on web portal context [27] and mobile apps [28] reached a similar conclusion that confirmation has a positive impact on satisfaction. Shiau et al. [29] verified the relationship between confirmation and satisfaction on blog users. Based on all these previous findings, we put forward the following hypotheses:

Hypothesis (H1). The experience confirmation of ICFP users has a positive effect on their satisfaction with ICFP technology or services.

Hypothesis (H2). The experience confirmation of ICFP users has a positive effect on the perceived usefulness of ICFP technology or services.

\subsubsection{Perceived Usefulness, Satisfaction, and Continuous Use Intention}

People develop an impression after using a certain information system at an early stage. When consumers use Internet consumer finance applications, they evaluate whether it solves actual problems (usefulness), which then affect their subsequent use. Users' previous experiences that made them feel the usefulness of information technologies increases their satisfaction with their increased experience, which then affects their behavioral decision as to whether they will continue to use it. Perceived usefulness was verified to have a positive effect on technology acceptance related behaviors $[3,30]$. We refer to perceived usefulness as the extent to which users of ICFPs meet their consumer needs after using the product, alleviating consumers' current economic pressure, and facilitating preferred consumer 
consumption in advance. Whether ICFPs can meet the consumer's needs is a key factor in determining whether users adopt and continue to use such consumer financial products. Therefore, we propose the following hypotheses:

Hypothesis (H3). Users' perceived usefulness of ICFPs has a positive effect on their satisfaction.

Hypothesis (H4). Users' perceived usefulness of ICFPs has a positive effect on their continuous use intention.

Satisfaction is the degree of psychological fulfillment after confirming the quality of the service. The more satisfied the user is with the previous experience, the more likely the user is to continue to use the service. Marketing research has shown that the major reason for a consumer's decision to re-purchase a product or their re-use intention is his/her level of satisfaction [31,32]. In this paper, when users' actual performance after use is greater than their psychological expectations before use, users will obtain higher satisfaction and are more willing to use or reuse Internet consumer financial platforms. Therefore, we propose the following hypothesis:

Hypothesis (H5). The satisfaction of users engaging with ICFPs positively influences their continuous use intention.

\subsection{Impulsive Buying in the Self-Control Theory}

\subsubsection{Credit Limit Misconception}

People's attitudes towards money, debt, and risk will affect people's shopping behavior, and thus affect their use of financial services [33]. According to the consumption cycle theory, people's consumption behavior is not only affected by current income, but also be affected by future income. ICFPs give people credit as consumption limits, which can be consumed in advance. This part of the limit or quota affects people's consumer psychology. When the credit card limit is larger, people are more likely to overspend. Veludo-de-Oliveira [21,34] introduced the concept of "beliefs of credit limit as additional income" (credit limit misconception or CLM), which differs from the illusion of income because it addresses the extent to which individuals believe that their credit limits are a part of their current income (and not future income). They found that individuals who take their credit limits as a part of their current income are prone to engage in impulsive buying more easily. Accordingly, we propose a hypothesis about CLM:

Hypothesis (H6). Credit limit misconception (CLM) positively affects impulsive buying behavior.

\subsubsection{Materialism}

Materialism is defined as an individual's "set of centrally held beliefs about the importance of possessions in one's life" [35]. Materialism means that people focus on the things they have, and they are used to judge a person's identity and status based on their belongings [36]. Today's society is full of consumerism, an illusion from shortlived materialism. Young people are prone to emotional anxiety under various marketing efforts. In order to alleviate this short-term anxiety, people tend to get psychological satisfaction through shopping, but this satisfaction is short-lived [37-39]. Materialism makes people short-sighted. They will not see the long-term backlog caused by heavy use of ICFPs. The long-term consumption above their financial capability reduces their ability to consume in the future and presents a new round of anxiety about money [40]. Importantly, an individual's inability to control their impulsive purchasing behavior is in part driven by the desire to gain social acceptance with peers [41]. Therefore, materialism leads to more frequent impulsive buying. Hence, we proposed a hypothesis as follows:

Hypothesis (H7). Materialism has a positive effect on impulsive buying behavior. 


\subsubsection{Interpersonal Influence}

Venkatesh et al. [42] defined social influence as the degree of influence an individual receives from people or the environment that is closely related to him/her. Extant literature has shown the significance of interpersonal influence, one of the most typical social influences, on impulsive buying behavior-e.g., Sharma et al. [43] proved that when interpersonal influence creates compulsion, consumers' self-control goes down, resulting in impulsive buying behavior. This is especially true for peer influence [44]. Therefore, we expect individuals to exhibit more frequent impulsive buying behavior when exposed to interpersonal influence. We proposed the hypothesis that:

Hypothesis (H8). Interpersonal influence has a positive effect on impulsive buying behavior.

\subsection{Impulsive Buying and Continuous Use Intention}

The credit quota or limits provided by ICFPs can meet not only users' rational financial demand, but also people's impulsive consumption demand $[45,46]$. People showing impulsive behavior give up a long-term standard of living for temporary satisfaction. Impulsive buying often weakens people's financial capability. It then precipitates a more frequent and heavy use of credit from ICFPs. The reliance on ICFPs will, however, push up users' individual debt, lowering their repayment capability and eventually making their continuous use intention not sustainable. Previous analysis of credit card user behavior confirmed the positive effect of impulsive shopping behavior on personal debt and insolvency [47], but neglected its effect on users' continuous use intention. Based on this rationale, we propose the following hypothesis:

Hypothesis (H9). Impulsive buying behavior of ICFP users has a positive effect on their continuous use intention.

ICFP users have a dual identity. They are not only users of information technology, but also consumers who use ICFPs to obtain credits for shopping. As an information system user, they may get addicted to the new technology as it can provide utility to users' daily life, according to the ECT-IS theory. As a consumer, they enjoy the additional purchase power endowed by consumer credits from ICFPs. They get lured to become heavily reliant on ICFPs, as predicted by the self-control theory. The dual identity leads to two channels that serve one purpose-continuous use intention of ICFP users. Therefore, we combine two theories to explain the continuous use intention of ICFP users. We also evaluate the role of occupation, income, gender, usage time, and education level in determining the continuous use intention of ICFP users. These are common control variables used in other works [47].

This array of hypotheses constructs a system of regression equations. We present them as a path diagram in Figure 2, as well as mathematical expressions as follows (Equations (1)-(4)).

$$
\begin{gathered}
\mathrm{PU}=\gamma_{10}+\gamma_{11} \mathrm{Con}+\varepsilon_{1} \\
\text { Sat }=\gamma_{20}+\gamma_{21} \mathrm{Con}+\beta_{21} \mathrm{PU}+\varepsilon_{2} \\
\mathrm{IB}=\gamma_{30}+\gamma_{31} \mathrm{CLM}+\gamma_{32} \mathrm{Ma}+\gamma_{33} \mathrm{II}+\varepsilon_{3} \\
\mathrm{CUI}=\gamma_{40}+\beta_{41} \mathrm{Sat}+\beta_{42} \mathrm{PU}+\beta_{43} \mathrm{IB}+\gamma_{4 i} x_{4 i}+\varepsilon_{4}
\end{gathered}
$$

where $x_{4 i}$ are control variables, $\gamma_{i j}$ represent structural parameters that relate independent variables to dependent variables, $\beta_{i j}$ stand for structural parameters relating a dependent variable to another dependent variable, and $\varepsilon_{i}(i=1,2,3,4)$ are stochastic error terms with an IID distribution, and Con = Conformation; Sat = Satisfaction; $\mathrm{Ma}=$ Materialism; $\mathrm{CLM}=$ Credit Limit Misconception; II = Interpersonal Influence; CUI = Continuous Use Intention; IB = Impulsive Buying; PU = Perceived usefulness. 


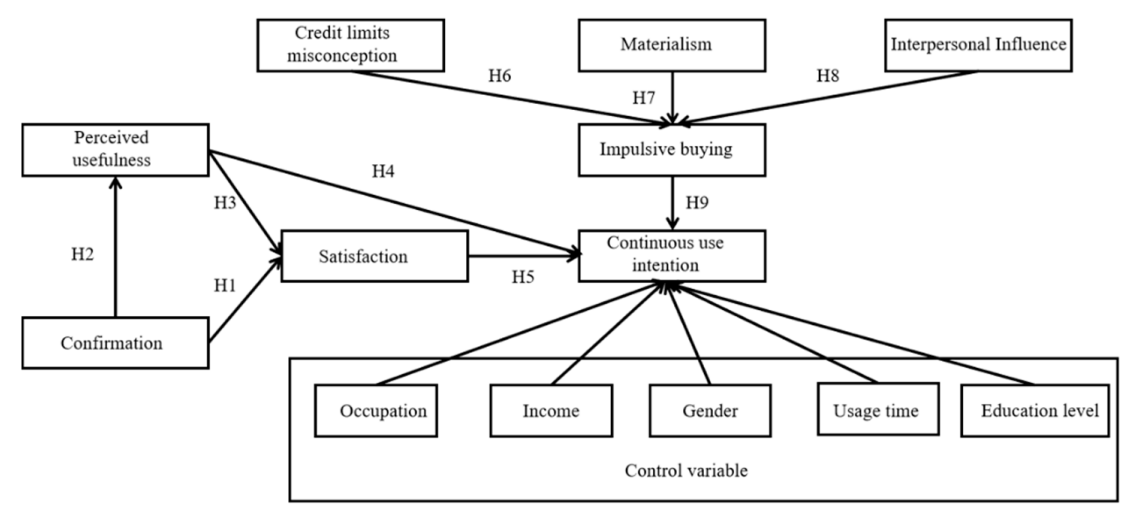

Figure 2. The research model.

\section{Data and Empirical Results}

\subsection{Data}

We used an online questionnaire platform, Wenjuanxing.com, to distribute questionnaires and collect data from Chinese ICFP users during March to May 2021. The measurement items for the eight constructs (perceived usefulness, satisfaction, confirmation, credit limits misconception, materialism, interpersonal influence, impulsive buying, and continuous use intention) were adopted from literature (see Table A1, Appendix for the questionnaire). All items were measured on a five-point Likert scale ranging from "strongly disagree" (1) to "strongly agree" (5) [48]. A total of 300 questionnaires were distributed. Since we studied on post acceptance behavior of ICFP users, those who do not have user experience in ICFPs are excluded. Finally, $244(N=244)$ responses were valid. We summarize demographic information about the respondents in Table 2.

Table 2. Demographic profile of respondents.

\begin{tabular}{|c|c|c|c|}
\hline Sample Size $N=244$ & Category & Number & $\%$ \\
\hline \multirow[b]{2}{*}{ Gender } & Male & 113 & 46.3 \\
\hline & Female & 131 & 53.7 \\
\hline \multirow{5}{*}{ Age } & $<18$ & 1 & 0.4 \\
\hline & $18-24$ & 102 & 41.8 \\
\hline & $25-30$ & 92 & 37.7 \\
\hline & $30-40$ & 38 & 15.6 \\
\hline & $>40$ & 11 & 4.5 \\
\hline \multirow{4}{*}{ Educational Level } & Junior high school & 10 & 4.1 \\
\hline & High school & 26 & 10.7 \\
\hline & Undergraduate & 133 & 54.5 \\
\hline & Graduate and above & 75 & 30.7 \\
\hline \multirow{6}{*}{ Occupation } & Student & 96 & 39.3 \\
\hline & Civil servant & 34 & 13.9 \\
\hline & Office worker & 81 & 33.2 \\
\hline & Self-employed & 17 & 7.0 \\
\hline & Social group staff & 3 & 1.2 \\
\hline & Others & 13 & 5.3 \\
\hline \multirow{5}{*}{$\begin{array}{l}\text { Monthly salary } \\
\text { (RMB) }\end{array}$} & $<1000$ & 51 & 20.9 \\
\hline & 1000-2999 & 45 & 18.4 \\
\hline & $3000-4999$ & 63 & 25.8 \\
\hline & 5000-7999 & 46 & 18.9 \\
\hline & $>8000$ & 39 & 16.0 \\
\hline \multirow{5}{*}{ Time of use (years) } & $<0.5$ & 20 & 8.2 \\
\hline & $0.5-1$ & 33 & 13.5 \\
\hline & $1-2$ & 72 & 29.5 \\
\hline & $2-4$ & 67 & 27.5 \\
\hline & $>4$ & 52 & 21.3 \\
\hline
\end{tabular}


Most respondents (79.5\%) were aged 18-30 (see Table 2). Respondents had a high level of education, including $54.5 \%$ of respondents having a bachelor's degree and $30.7 \%$ having a master's degree or above. In addition, most of the respondents' $(25.8 \%)$ monthly incomes are around RMB 3000-4999. The majority of users have been using ICFPs for at least one year. Only $21.7 \%$ of respondents have less-than one year of ICFP user experience.

\subsection{Reliability and Validity}

To test reliability and validity of the model, SPSS 25.0 and Amos 22.0 were used. The reliability of the questionnaire data was tested by the internal consistency of the questionnaire using Cronbach's $\alpha$ [49]. A Cronbach's $\alpha$ larger than 0.7 indicates the measurement items are internally consistent. All Cronbach's $\alpha$ in Table 3 are greater than the recommended value of 0.7 [50].

Table 3. Statistics of reliability test.

\begin{tabular}{|c|c|c|c|c|c|c|}
\hline Indicators & Mean & SE & Factor loading & Cronbach's $\alpha$ & CR & AVE \\
\hline PU1 & \multirow{3}{*}{4.0191} & \multirow{3}{*}{0.861} & 0.715 & \multirow{3}{*}{0.791} & \multirow{3}{*}{0.7875} & \multirow{3}{*}{0.554} \\
\hline PU2 & & & 0.694 & & & \\
\hline PU3 & & & 0.818 & & & \\
\hline Con1 & \multirow{3}{*}{3.9454} & \multirow{3}{*}{0.8923} & 0.821 & \multirow{3}{*}{0.889} & \multirow{3}{*}{0.8887} & \multirow{3}{*}{0.727} \\
\hline Con2 & & & 0.877 & & & \\
\hline Con3 & & & 0.859 & & & \\
\hline CLM1 & \multirow{4}{*}{2.8986} & \multirow{4}{*}{1.3253} & 0.960 & \multirow{4}{*}{0.92} & \multirow{4}{*}{0.9215} & \multirow{4}{*}{0.7467} \\
\hline CLM2 & & & 0.817 & & & \\
\hline CLM3 & & & 0.806 & & & \\
\hline CLM4 & & & 0.865 & & & \\
\hline III & \multirow{2}{*}{4.0635} & \multirow{2}{*}{0.7903} & 0.859 & \multirow{2}{*}{0.805} & \multirow{2}{*}{0.8077} & \multirow{2}{*}{0.6778} \\
\hline II2 & & & 0.786 & & & \\
\hline Sat1 & \multirow{3}{*}{3.9365} & \multirow{3}{*}{0.8499} & 0.871 & \multirow{3}{*}{0.867} & \multirow{3}{*}{0.8631} & \multirow{3}{*}{0.6776} \\
\hline Sat2 & & & 0.833 & & & \\
\hline Sat3 & & & 0.763 & & & \\
\hline $\mathrm{Ib} 1$ & \multirow{4}{*}{3.0861} & \multirow{4}{*}{1.1627} & 0.776 & \multirow{4}{*}{0.887} & \multirow{4}{*}{0.8859} & \multirow{4}{*}{0.6613} \\
\hline $\mathrm{Ib} 2$ & & & 0.911 & & & \\
\hline $\mathrm{Ib} 3$ & & & 0.814 & & & \\
\hline $\mathrm{Ib} 4$ & & & 0.742 & & & \\
\hline CUI1 & \multirow{3}{*}{3.1875} & \multirow{3}{*}{1.0912} & 0.847 & \multirow{3}{*}{0.899} & & \\
\hline CUI2 & & & 0.85 & & 0.9031 & 0.7566 \\
\hline CUI3 & & & 0.911 & & & \\
\hline Ma1 & & & 0.677 & & 07411 & 05932 \\
\hline Ma2 & 3.4857 & $1.05 \% 4$ & 0.850 & 0.726 & 0.1411 & 0.5932 \\
\hline
\end{tabular}

Note: Con $=$ Conformation; Sat $=$ Satisfaction; Ma $=$ Materialism $;$ CLM $=$ Credit Limit Misconception $\mathrm{II}=$ Interpersonal Influence; CUTI = Continuous Use Intention; IB = Impulsive Buying; PU = Perceived usefulness.

In order to determine the convergent validity of each variable, we performed confirmatory factor analysis (CFA), and then tested the composite reliability (CR) and average variance extracted (AVE) of each variable. In Table 3, we can see that the CR of each variable is greater than 0.7. AVE is also greater than the recommended value of $>0.5$ [50]. This implies that the measurement items reflect the constructs well.

We used model comparison for the discriminant validity test (Table 4) [51,52]. Compared with the other four models, the eight-factor model represented by Model 1 has the best fitting effect for the actual data $\left(\chi^{2}=486.04, \mathrm{df}=247, \chi^{2} / \mathrm{df}=1.968\right.$, RESEA $=0.063$, $\mathrm{CFI}=0.946$; IFI $=0.947$ ). All fitness indicators are higher than the recommended values, indicating that the eight variables in our model have good discriminant validity. 
Table 4. Comparison of measurement models.

\begin{tabular}{|c|c|c|c|c|c|c|c|c|}
\hline Model & Descriptions & $x^{2}$ & df & $\Delta x^{2}$ & $x^{2} / \mathrm{df}$ & RESEA & CFI & IFI \\
\hline Model 1 & $\begin{array}{l}8 \text { Factors: PU, Sat, CLM, II, Con, } \\
\text { CUI, IB and Ma. }\end{array}$ & 486.04 & 247 & & 1.968 & 0.063 & 0.946 & 0.947 \\
\hline Model 2 & $\begin{array}{l}6 \text { Factors: Con, Sat and PU were } \\
\text { combined into one factor }\end{array}$ & 582.066 & 260 & $96.026 * * *$ & 2.241 & 0.071 & 0.927 & 0.828 \\
\hline Model 3 & $\begin{array}{l}4 \text { Factors: Con, Sat, Ma, CLM and } \\
\text { PU were combined into one factor }\end{array}$ & 1510.098 & 269 & $1024.058^{* * *}$ & 5.600 & 0.138 & 0.720 & 0.722 \\
\hline Model 4 & $\begin{array}{l}2 \text { Factors: CON, Sat, II, Ma, CLM, } \\
\text { CUI and PU were combined into } \\
\text { one factor }\end{array}$ & 1750.104 & 274 & $1264.064^{* * *}$ & 6.389 & 0.149 & 0.606 & 0.669 \\
\hline Model 5 & $\begin{array}{l}1 \text { Factors: CON, Sat, II, Ma, CLM, } \\
\text { CUI, IB and PU were combined } \\
\text { into one factor }\end{array}$ & 2209.961 & 275 & $1723.921^{* * *}$ & 8.034 & 0.170 & 0.563 & 0.566 \\
\hline
\end{tabular}

Note. RMSEA: root mean square error of approximation; CFI: comparative fit index; IFI: incremental fit index. ${ }^{* * *}$ Significance level $p<0.001$; Con = conformation; Sat = satisfaction; $\mathrm{Ma}=$ materialism; $\mathrm{CLM}=$ credit limit misconception; $\mathrm{II}=$ interpersonal influence; $\mathrm{CUI}=$ continuous use intention; $\mathrm{IB}=$ impulsive buying; $\mathrm{PU}=$ perceived usefulness.

Finally, we verified the overall goodness-of-fit of the model. We used confirmatory factor analysis (CFA) to verify the measurement of the model in Table 5. All the indicators met the requirements of the recommended values.

Table 5. Goodness-of-fit test.

\begin{tabular}{ccccccc}
\hline Goodness-of-Fit Measures & $\chi^{2} / \mathbf{d f}$ & RESEA & GFI & AGFI & CFI & IFI \\
\hline Recommended value [53-57] & $\leq 3$ & $\leq 0.08$ & $\geq 0.8$ & $\geq 0.8$ & $\geq 0.9$ & $\geq 0.9$ \\
CFA model & 1.968 & 0.063 & 0.864 & 0.821 & 0.946 & 0.947 \\
Structural model & 1.749 & 0.056 & 0.865 & 0.823 & 0.943 & 0.944 \\
\hline
\end{tabular}

Note: The ratio of chi-square statistics to degree of freedom $\left(\mathrm{X}^{2} / \mathrm{df}\right)$, root mean square error of approximation (RMSEA), goodness-of-fit index (GFI), adjusted goodness-of-fit index (AGFI), comparative fit index (CFI), normed fit index (NFI).

\subsection{Hypothesis Testing}

We then tested the hypotheses using a structural equation modeling (SEM) approach. Results support all of the hypotheses. Their standardized path coefficients are shown in Figure 3.

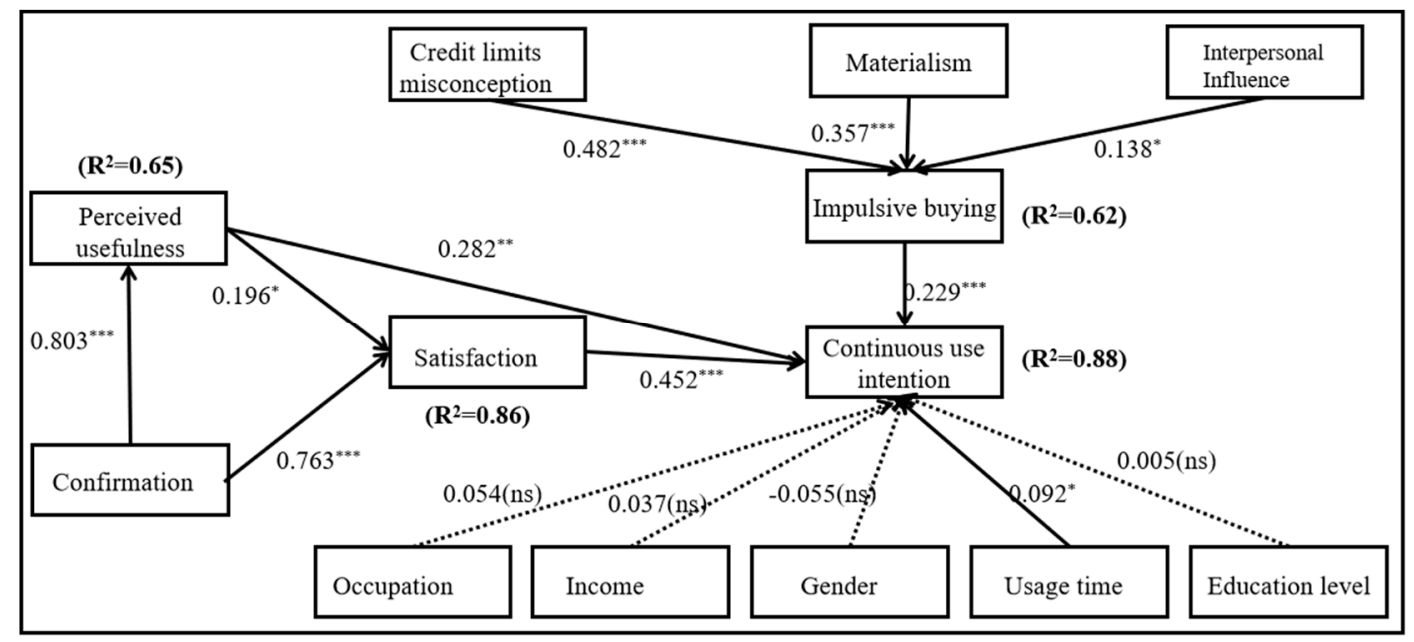

Figure 3. Path analysis of the research model. Notes: $\mathrm{R}^{2}$ is coefficient of determinant, indicating the prediction power of a dependent variable; ${ }^{*} p<0.05 ;{ }^{* *} p<0.01$; ${ }^{* *} p<0.001$; (ns) $=$ Not supported. 
Hypotheses relating to ECT-IS theories are all verified. The relationship between conformation and perceived usefulness $(b=0.803, p<0.001)$ is significant, which means that users of ICFPs based on information technology adjust their previous expectations according to their own experience. If their expectations are met when using ICFPs, a user's satisfaction $(b=0.76, p<0.001)$ will also increase. With the increase of satisfaction, users are more likely to continue to use ICFPs in the future. The test results also verify that the relationship between satisfaction and continuous use intention $(b=0.452, p<0.001)$ is significant. The relationship between perceived usefulness and satisfaction $(b=0.196$, $p<0.05)$ and continuous use intention $(b=0.282, p<0.01)$ is significant. These results indicate that ICFPs should build and optimize the information technology platform in order to better users' experience in the process of using ICFPs, and finally cultivate their loyalty.

$\mathrm{H6}, \mathrm{H7}$, and $\mathrm{H} 8$ are all valid. Among the factors that affect impulsive buying, CLM $(b=0.482, p<0.001)$ has the most significant direct impact on impulsive buying. The second is materialism $(b=0.355, p<0.001)$. Although the relationship between interpersonal influence and impulsive buying is significant, its influence is the lowest with a coefficient of $0.138(p<0.05)$. We can also see from the results of Figure 3 that the relationship between impulsive buying and the continuous use intention $(b=0.229, p<0.001)$ is significant and H9 is valid [58].

All the control variables have no significant effect on continuous use intention except usage time. Davies and Lea [59] found that women were more likely than men to carry credit card debt, whereas Wang et al. [60] found that men have a higher likelihood of having revolving credit card debt. However, our empirical result did not support any of these gender impact on continuous use intention. The significant impact of usage time is supported by the findings by Choi et al. [61] on the formation of mobile short video platform users' habits. It implies that, regardless of financial services for online shoppers or short video users, the user's experiences on the information technology will not be different in attracting users.

In addition, our model shows good prediction power $\left(R^{2}\right)$. The model explains $73 \%$ of the variance of continuous usage intention. Credit limits misconception, materialism, and interpersonal influence together explained $62 \%$ of the variance of impulsive buying. The model also explains $86 \%$ of the variance of satisfaction, and $64 \%$ of perceived usefulness.

\section{Discussion and Policy Implications}

We find that both satisfaction and impulsive buying are significantly affecting continuous use intention. Satisfaction $(b=0.452)$ has a much larger impact on continuous use intention than impulsive buying $(b=0.229)$, suggesting that ICFPs have a sound platform for sustainable management coming from loyalty of the consumers. Given that impulsive buying weakens ICFP users' repayment capability, ICFPs in China could lay more emphasis on technology innovations rather than the credit abuse issuing power to seduce users into impulsive buying. Besides, our empirical findings conclude that confirmation and perceived usefulness are the two major antecedents of satisfaction, implying that people will continue to use Internet financial services if their previous expectations for its usefulness are satisfied in use, supporting the previous research on continuous use intention of mobile bank users [62]. ICFP users expect two dimensions of usefulness: The first is software use experience, implying that ICFPs must ensure that the operational process of their applications is simple, efficient, and convenient. The second factor for usefulness is the sufficiency of credit issuing. Nonetheless, however, this second factor posed contradictory situation to restrain users' impulsive buying-more credit issuing renders in more frequent impulsive buying due to credit limit misconception. Therefore, Chinese ICFPs may create a more precise user profile portrait to provide sufficient but not overwhelming credits to Chinese users in order limit their irrational consumption behavior. For this purpose, in the near future, Chinese ICFPs may consider advancing big data and deep learning techniques to provide a more accurate characterization of consumers' behavior. 
Additionally, ICFPs need to invest more in platform optimization to make the operation of borrowing and post-installment repayment easier and more efficient for Chinese users. For example, when a user enters the operational interface of those ICFPs, there should be obvious tips on the operational steps, as well as some warning concerning credit abuse. For experienced loyal users, the platform providers can optimize the financial services for them to be completed with one click based on their behavioral data: that is, they only need to enter their fingerprints on their mobile phones to complete the loan or repayment operation. Only if the operating system is simple and efficient, and if users have a good experience, will they have the intention to continue using it.

The positive effect of impulsive buying on continuous use intention is non-negligible. Stakeholders, such as the central government and local society, must recognize that this pathway to retain ICFP users is unsustainable. Impulsive buying weakens debt repayment capacity of ICFP users and traps them under heavy debt, which will finally make them unable to use ICFPs anymore. This has been demonstrated in previous studies on credit card users. Pirog et al. found that impulsive buying can be used as a mediating variable to influence credit card misuse [63]. Abrantes-Braga et al. [22] found that impulsive buying behaviors can lead to risky indebtedness, thereby worsening their own financial situation. Therefore, the impulsive buying behavior of ICFP users must be restrained for the sustainable development of ICFP industry. For this purpose, the Chinese government should engage in more proactive participation in the regulatory practice of local ICFPs. This may be done through deeper public/private partnership. Developing countries like China may not have a sound historical background of credit card experiences, and thus the optimizing future direction on the ICFP industry is much more important for their transition toward an advanced economy.

Our results show that credit limit misconception, materialism, and interpersonal influence have significant positive effect of impulsive buying. To our surprise, credit limit misconception has the greatest direct impact on impulsive buying $(b=0.482)$. This cognitive bias is mainly the result of a lack of financial literacy [64]. In this case, we suggest that Chinese government should organize resources to improve ICFP user financial literacy and to prevent individual financial crisis caused by overuse ICFPs. Similar things have been done in EU after the 2008 crisis [58]. Besides, the Chinese government should also tighten regulatory measures and build legal construction to prevent the disorderly expansion of ICFPs through seducing users' irrational consumption behaviors, such as credit over-issuing. In addition, the government may make clear instructions on the financial service compulsorily for Chinese ICFPs to protect both companies and users. The effect of materialism $(b=0.357)$ on impulsive buying is smaller than that of credit limit misconception. Nonetheless, it indicates that the pursuit of materialism can lead to irrational consumption behavior of ICFP users. Pradhan et al. [65] also verified that materialism influences credit card uses and increases the propensity for impulsive buying. The positive effect of interpersonal influence on impulsive buying is even smaller $(b=0.138)$. Nonetheless, they suggest that the behavioral intention of Chinese ICFP users are influenced by social norms. Therefore, it is necessary to increase the publicity of rational consumption behavior in society. For example, Chinese schools, colleges, and universities may carry out activities and courses to educate the younger generation to engage in rational consumption behavior. In popular social media outlets, Chinese government and ICFPs should increase the audit and control of propaganda and media content with materialism mentality so as to alter the culture of irrational consumption in Chinese young people.

With the development of information technology, the competition among ICFPs will become more and more serious, and thus, each ICFP wants to survive and develop its own product characteristics. The results of the control variables in this paper also exactly verify this point. This requires platform builders to develop their own features on the basis of the popular functions to enhance the frequency: for example, they can try to add some interactive mechanisms and game features to enhance users' frequency of use and increase the possibility of their continued use in the future. 


\section{Conclusive Remarks}

To identify a sustainable avenue for ICFP development in China, this empirical research analyzed the post-adoption behavioral intention of Chinese ICFP users. We identified their dual identities: users of information technology, and consumers using credit balance. We then developed a new hybrid model through integrating the ECT-IS model and self-control theory to explain continuous use intention of ICFP users.

In conclusion, we believe that it is sensible for ICFPs to lay out their user retention strategy in a sustainable manner. To do this, ICFPs must not compromise the welfare of their users, which is feasible since impulsive buying is not the sole antecedent of continuous use intention. We call on other researchers to explore future research avenues and dive deep into ICFP user behaviors to propose more nuanced strategies for ICFPs across different cultures.

This work is also subject to some limitations. First, we limited our targeted population as Chinese only. Future works may consider a sample of different geographic locations and find possible heterogeneities in those samples. Similarly, geographic location of ICFP users may be another significant control variable for our model, which should be considered in future works. Secondly, the interviewees of this paper are mostly students and young office workers, which could be diversified. In addition, our dataset lacks a longitudinal dimension. Future works may consider time-varying behavioral intention of ICFP users. Finally, the consequence of ICFP users' continuous use intention has not been explored in detail. Future works should advance the theoretical model to understand behavioral consequences of continuous ICFP users.

Author Contributions: Conceptualization, M.C.; Methodology, M.C. and F.Y.; Validation, Y.C.; Data curation, F.Y.; Writing-original draft preparation, M.C.; Writing-review and editing, Y.C.; Visualization, F.Y.; Supervision, Y.C.; Funding acquisition, Y.C. All authors have read and agreed to the published version of the manuscript.

Funding: This study was supported by the National Research Foundation of Korea in the year 2021 (Grant No. NRF-2019R1A2C1005326).

Institutional Review Board Statement: Not applicable.

Informed Consent Statement: Informed consent was obtained from all subjects involved in the study.

Data Availability Statement: Not applicable.

Conflicts of Interest: The authors declare no conflict of interest.

Appendix A. Questionnaire

Table A1. Appendix for the questionnaire.

\begin{tabular}{|c|c|c|}
\hline PU1 & $\begin{array}{l}\text { Choosing Internet consumer financial services allows me to consume my favorite products/services in } \\
\text { advance. }\end{array}$ & \multirow{3}{*}{ [6] } \\
\hline PU2 & Using Internet consumer financial services can alleviate my temporary "strain". & \\
\hline PU3 & Overall, Internet consumer financial services are useful to me. & \\
\hline CO1 & \multirow{3}{*}{$\begin{array}{l}\text { The experience of using Internet consumer financial products is better than I expected. } \\
\text { The goods / services provided by Internet consumer financial products are better than I expected. } \\
\text { I expect the use of Internet consumer financial products to be convenient. }\end{array}$} & \multirow{3}{*}[6]{} \\
\hline $\mathrm{CO} 2$ & & \\
\hline $\mathrm{CO} 3$ & & \\
\hline Sat1 & I think the decision to use Internet consumer financial service is wise. & \multirow{3}{*}[6]{} \\
\hline Sat2 & I think using Internet consumer financial service is a good choice. & \\
\hline Sat3 & Overall, I am satisfied with the experience of Internet consumer financial service. & \\
\hline CLM1 & \multirow{4}{*}{$\begin{array}{l}\text { I add my Internet consumer financial limits to my budget as if they were a part of my regular income. } \\
\text { When I am planning my budget, I consider my Internet consumer financial limits to be extra income. } \\
\text { When I use Internet consumer financial limits to pay, I will not feel any difference from my bank card } \\
\text { balance payment. } \\
\text { In my subconscious mind, I don't think that Internet consume financial balance is too different from } \\
\text { my bank card balance. }\end{array}$} & \multirow{4}{*}[22,34]{} \\
\hline CLM2 & & \\
\hline CLM3 & & \\
\hline CLM4 & & \\
\hline
\end{tabular}


Table A1. Cont.

\begin{tabular}{cc}
\hline Ma1 & $\begin{array}{c}\text { I admire people who own expensive homes, cars, and clothes. } \\
\text { Ma2 }\end{array}$ \\
\hline IB1 & The things I own, say a lot to others in terms of how my life is. \\
IB2 & I often buy things spontaneously. \\
IB3 & With my consumer finance I buy what I want when I want it. \\
IB4 & "I see it, I buy it" sometimes describes me. \\
\hline II1 & My friends think it's acceptable to use Internet consumer financial service. \\
II2 & My friends also have Internet consumer financial debt and some higher than me. \\
\hline CUI1 & I will probably not stop using the services provided by Internet consumer finance platforms. \\
CUI2 & I will continue to use the amount on the Internet consumer finance platform as the payment method \\
CUI3 & for my daily consumption.
\end{tabular}

\section{References}

1. Wang, X. Research on New Development Mode of Internet Consumer Finance in the Era of E-Commerce. In Proceedings of the 2020 International Conference on Social Sciences and Innovative Economy (SSIE2020), Shaoxing, China, 28-30 September 2020.

2. Joireman, J.; Kees, J.; Sprott, D. Concern with Immediate Consequences Magnifies the Impact of Compulsive Buying Tendencies on College Students' Credit Card Debt. J. Consum. Aff. 2010, 44, 155-178. [CrossRef]

3. Davis, F.D. Perceived Usefulness, Perceived Ease of Use, and User Acceptance of Information Technology. MIS Q. 1989, 13, 319-340. [CrossRef]

4. Oliver, R.L. A Cognitive Model of the Antecedents and Consequences of Satisfaction Decisions. J. Mark. Res. 1980, 17, 460-469. [CrossRef]

5. Pee, L.G.; Jiang, J.; Klein, G. Signaling Effect of Website Usability on Repurchase Intention. Int. J. Inf. Manag. 2018, 39, 228-241. [CrossRef]

6. Bhattacherjee, A. Understanding Information Systems Continuance: An Expectation-Confirmation Model. MIS Q. 2001, 25, 351-370. [CrossRef]

7. Oghuma, A.P.; Libaque-Saenz, C.F.; Wong, S.F.; Chang, Y. An Expectation-Confirmation Model of Continuance Intention to Use Mobile Instant Messaging. Telemat. Inform. 2016, 33, 34-47. [CrossRef]

8. Rahi, S.; Ghani, M.A.J. Integration of Expectation Confirmation Theory and Self-Determination Theory in Internet Banking Continuance Intention. J. Sci. Technol. Policy Manag. 2019, 10, 533-550. [CrossRef]

9. Shiau, W.-L.; Yuan, Y.; Pu, X.; Ray, S.; Chen, C.C. Understanding Fintech Continuance: Perspectives from Self-Efficacy and ECT-IS Theories. Ind. Manag. Data Syst. 2020, 120, 1659-1689. [CrossRef]

10. Zhou, W.; Tsiga, Z.; Li, B.; Zheng, S.; Jiang, S. What Influence Users' E-Finance Continuance Intention? The Moderating Role of Trust. Ind. Manag. Data Syst. 2018, 118, 1647-1670. [CrossRef]

11. Khan, U.; Dhar, R.; Wertenbroch, K. A Behavioral Decision Theory Perspective on Hedonic and Utilitarian Choice. In Inside Consumption; Routledge: London, UK, 2005; pp. 166-187.

12. Ouellette, J.A. Wood, Wendy, Habit and Intention in Everyday Life: The Multiple Processes by Which Past Behavior Predicts Future Behavior. Psychol. Bull. 1998, 124, 54. [CrossRef]

13. Dennis, W.R. The Buying Impulse. J. Consum. Res. 1987, 14, 189-199.

14. Baumeister, R.F. Yielding to Temptation: Self-Control Failure, Impulsive Purchasing, and Consumer Behavior. J. Consum. Res. 2002, 28, 670-676. [CrossRef]

15. Schmeichel, B.J.; Vohs, K.D.; Baumeister, R.F. Intellectual Performance and Ego Depletion: Role of the Self in Logical Reasoning and Other Information Processing. J. Personal. Soc. Psychol. 2003, 85, 33-46. [CrossRef]

16. Norvilitis, J.; Mendes, W. Attitudes toward Credit and Finances among College Students in Brazil and the United States. J. Bus. Theory Pract. 2013, 1, 132. [CrossRef]

17. Frigerio, M.; Ottaviani, C.; Vandone, D. A Meta-Analytic Investigation of Consumer over-Indebtedness: The Role of Impulsivity. Int. J. Consum. Stud. 2020, 44, 328-342. [CrossRef]

18. Rook, D.W.; Gardner, M.P. In the Mood: Impulse Buying's Affective Antecedents. Res. Consum. Behav. 1993, 6, 1-28.

19. Dittmar, H.; Drury, J. Self-Image-Is It in the Bag? A Qualitative Comparison between "Ordinary" and "Excessive" Consumers. J. Econ. Psychol. 2000, 21, 109-142. [CrossRef]

20. Hausman, A. A Multi-Method Investigation of Consumer Motivations in Impulse Buying Behavior. J. Consum. Mark. 2000, 17, 403-426. [CrossRef]

21. Di Martino, A.; Yan, C.; Li, Q.; Denio, E.; Castellanos, F.X.; Alaerts, K.; Anderson, J.S.; Assaf, M.; Bookheimer, S.Y.; Dapretto, M. The Autism Brain Imaging Data Exchange: Towards a Large-Scale Evaluation of the Intrinsic Brain Architecture in Autism. Mol. Psychiatry 2014, 19, 659-667. [CrossRef] 
22. Abrantes-Braga, F.D.M.A.; Veludo-de-Oliveira, T. Help Me, I Can't Afford It! Antecedents and Consequence of Risky Indebtedness Behaviour. Eur. J. Mark. 2020, 54, 2223-2244. [CrossRef]

23. Verplanken, B.; Herabadi, A. Individual Differences in Impulse Buying Tendency: Feeling and No Thinking. Eur. J. Personal. 2001, 15, S71-S83. [CrossRef]

24. Luo, H.; Chen, J.; Li, S.; Nie, Y.; Wang, G. Social Exclusion and Impulsive Buying among Chinese College Students: The Mediating Role of Self-Esteem and the Moderating Role of Risk Preference. Int. J. Environ. Res. Public Health 2021, 18, 11027. [CrossRef]

25. He, H.; Kukar-Kinney, M.; Ridgway, N.M. Compulsive Buying in China: Measurement, Prevalence, and Online Drivers. J. Bus. Res. 2018, 91, 28-39. [CrossRef]

26. Festinger, L. Cognitive Dissonance. Sci. Am. 1962, 207, 93-106. [CrossRef] [PubMed]

27. Lin, C.S.; Wu, S.; Tsai, R.J. Integrating Perceived Playfulness into Expectation-Confirmation Model for Web Portal Context. Inf. Manag. 2005, 42, 683-693. [CrossRef]

28. Chou, C.; Chiu, C.; Ho, C.; Lee, J. Understanding Mobile Apps Continuance Usage Behavior and Habit: An ExpectanceConfirmation Theory. In Proceedings of the PACIS 2013, Jeju Island, Korea, 18-22 June 2013.

29. Shiau, W.-L.; Luo, M.M. Continuance Intention of Blog Users: The Impact of Perceived Enjoyment, Habit, User Involvement and Blogging Time. Behav. Inf. Technol. 2013, 32, 570-583. [CrossRef]

30. Venkatesh, V.; Davis, F.D. A Theoretical Extension of the Technology Acceptance Model: Four Longitudinal Field Studies. Manag. Sci. 2000, 46, 186-204. [CrossRef]

31. Anderson, E.W.; Sullivan, M.W. The Antecedents and Consequences of Customer Satisfaction for Firms. Mark. Sci. 1993, 12, 125-143. [CrossRef]

32. Armstrong, G.; Adam, S.; Denize, S.; Kotler, P. Principles of Marketing; Pearson Australia: Melbourne, Australia, 2014.

33. Wang, L.; Lv, W.; Jiang, L. The Impact of Attitude Variables on the Credit Debt Behavior. Nankai Bus. Rev. Int. 2011, 2, 120-139. [CrossRef]

34. Abrantes-Braga, F.D.M.; Veludo-De-Oliveira, T. Development and Validation of Financial Well-Being Related Scales. Int. J. Bank Mark. 2019, 37, 1025-1040. [CrossRef]

35. Richins, M.L.; Dawson, S. A Consumer Values Orientation for Materialism and Its Measurement: Scale Development and Validation. J. Consum. Res. 1992, 19, 303-316. [CrossRef]

36. Limbu, Y.B.; Huhmann, B.A.; Xu, B. Are College Students at Greater Risk of Credit Card Abuse? Age, Gender, Materialism and Parental Influence on Consumer Response to Credit Cards. J. Financ. Serv. Mark. 2012, 17, 148-162. [CrossRef]

37. Bernthal, M.J.; Crockett, D.; Rose, R.L. Credit Cards as Lifestyle Facilitators. J. Consum. Res. 2005, 32, 130-145. [CrossRef]

38. Eastman, J.K.; Iyer, R.; Thomas, S.P. The Impact of Status Consumption on Shopping Styles: An Exploratory Look at the Millennial Generation. Mark. Manag. J. 2013, 23, 57-73.

39. Sidoti, P.M.; Devasagayam, R. Credit Cards and College Students: Effect of Materialism and Risk Attitude on Misuse. Mark. Manag. J. 2010, 20, 64-79.

40. Shapiro, G.K.; Burchell, B.J. Measuring Financial Anxiety. J. Neurosci. Psychol. Econ. 2012, 5, 92-103. [CrossRef]

41. Peltier, J.W.; Pomirleanu, N.; Endres, M.; Markos, E. Psycho-Social Factors Impacting Credit Acquisition and Use by College Students. In Financial Literacy and the Limits of Financial Decision-Making; Palgrave Macmillan: Cham, Switzerland, 2016; pp. 177-200. [CrossRef]

42. Venkatesh, V.; Morris, M.G.; Davis, G.B.; Davis, F.D. User Acceptance of Information Technology: Toward a Unified View. MIS Q 2003, 27, 425-478. [CrossRef]

43. Sharma, P.; Sivakumaran, B.; Marshall, R. Impulse Buying and Variety Seeking: A Trait-Correlates Perspective. J. Bus. Res. 2010, 63, 276-283. [CrossRef]

44. Luo, X. How Does Shopping with Others Influence Impulsive Purchasing? J. Consum. Psychol. 2005, 15, 288-294. [CrossRef]

45. Lai, C. How Financial Attitudes and Practices Influence the Impulsive Buying Behavior of College and University Students. Soc. Behav. 2010, 38, 373-380. [CrossRef]

46. Rook, D.W.; Fisher, R.J. Normative Influences on Impulsive Buying Behavior. J. Consum. Res. 1995, 22, 305-313. [CrossRef]

47. Wang, J.; Xiao, J.J. Buying Behavior, Social Support and Credit Card Indebtedness of College Students. Int. J. Consum. Stud. 2009, 33, 2-10. [CrossRef]

48. Likert, R. A Technique for the Measurement of Attitudes. Arch. Psychol. 1932, 22, 55.

49. Nunnally, J.C. Psychometric Theory, 2nd ed.; McGraw-Hill: New York, NY, USA, 1978.

50. Fornell, C.; Larcker, D.F. Evaluating Structural Equation Models with Unobservable Variables and Measurement Error. J. Mark. Res. 1981, 18, 39-50. [CrossRef]

51. Chen, M.; Chen, C.C.; Sheldon, O.J. Relaxing Moral Reasoning to Win: How Organizational Identification Relates to Unethical Pro-Organizational Behavior. J. Appl. Psychol. 2016, 101, 1082-1096. [CrossRef] [PubMed]

52. Hair, J.F. Multivariate Data Analysis, 7th ed.; Prentice Hall: Upper Saddle River, NJ, USA, 2009.

53. Bagozzi, R.P.; Yi, Y. On the Evaluation of Structural Equation Models. J. Acad. Mark. Sci. 1988, 16, 74-94. [CrossRef]

54. Bentler, P.M.; Bonett, D.G. Significance Tests and Goodness of Fit in the Analysis of Covariance Structures. Psychol. Bull. 1980, 88, 588. [CrossRef]

55. Browne, M.W.J. Testing Structural Equation Models, Alternative Ways of Assessing Model Fit; SAGE Publications: London, UK, 1993. 
56. Gefen, D.; Straub, D.; Boudreau, M. Structural Equation Modeling and Regression: Guidelines for Research Practice. Commun. Assoc. Inf. Syst. 2000, 4, 7. [CrossRef]

57. Scott, J.E. The Measurement of Information Systems Effectiveness: Evaluating a Measuring Instrument. ACM Sigmis Database Adv. Inf. Syst. 1995, 26, 43-61. [CrossRef]

58. Ottaviani, C.; Vandone, D. Financial Literacy, Debt Burden and Impulsivity: A Mediation Analysis. Econ. Notes 2017, 47, 439-454. [CrossRef]

59. Davies, E.; Lea, S.E.G. Student Attitudes to Student Debt. J. Econ. Psychol. 1995, 16, 663-679. [CrossRef]

60. Wang, L.; Malhotra, N.K.; Lu, W. Determinants of Credit Card Debt: Differentiating between Revolving Credit Debt and Petty Installment Loan in China. J. Consum. Behav. 2014, 13, 294-302. [CrossRef]

61. Choi, Y.; Wen, H.; Chen, M.; Yang, F. Sustainable Determinants Influencing Habit Formation among Mobile Short-Video Platform Users. Sustainability 2021, 13, 3216. [CrossRef]

62. Yuan, S.; Liu, Y.; Yao, R.; Liu, J. An Investigation of Users' Continuance Intention towards Mobile Banking in China. Inf. Dev. 2014, 32, 20-34. [CrossRef]

63. Pirog, S.F.; Roberts, J.A. Personality and Credit Card Misuse among College Students: The Mediating Role of Impulsiveness. J. Mark. Theory Pract. 2007, 15, 65-77. [CrossRef]

64. Ibrahim, M.E.; Alqaydi, F.R. Financial Literacy, Personal Financial Attitude, and Forms of Personal Debt among Residents of the UAE. Int. J. Econ. Financ. 2013, 5, 126. [CrossRef]

65. Pradhan, D.; Israel, D.; Jena, A.K. Logistics, Materialism and Compulsive Buying Behaviour: The Role of Consumer Credit Card Use and Impulse Buying. Asia Pac. J. Mark. 2018, 30, 1239-1258. [CrossRef]

66. Thomas, M.; Desai, K.; Seenivasan, S. How Credit Card Payments Increase Unhealthy Food Purchases: Visceral Regulation of Vices. J. Consum. Res. 2011, 38, 126-139. [CrossRef]

67. Limerick, L.; Peltier, J. The Effects of Self-Control Failures on Risky Credit Card Usage. Mark. Manag. 2014, 24, 149-161. 